\title{
DEVELOPMENT STRATEGY OF RICE ORGANIC FARMING SUSTAINABILITY TOWARDS FOOD SAFETY: A CASE STUDY IN KEDIRI-INDONESIA
}

\author{
Haryati N. \\ Department of Agricultural Social Economics, Faculty of Agriculture, \\ University of Brawijaya, Indonesia \\ Adi S.M. \\ Department of Communication, Faculty of Social and Political Science, \\ University of Brawijaya, Indonesia \\ *E-mail: noviharyati@ub.ac.id
}

\begin{abstract}
Organic farming is a way of farming that does not use chemicals as fertilizers and pesticides. In this way, what comes from the soil is returned to the soil so that the sustainability of the environment is maintained and the quality of the plant produced is guaranteed. This is in contrast to conventional rice farming that is still using fertilizers and chemical pesticides that are easily dispersed to obtain great results of harvest yield. This study aims to understand: (1) the characteristics of organic rice farmers; (2) organic farming implementation; and (3) to give recommendation strategy to develop organic rice farming in Kepung Subdistrict Kediri. This is a descriptive-qualitative research, primary data was collected through interview with 30 farmers in May-June 2017. Data were analyzed descriptively by using information on farming system conducted by farmer, then, SWOT analysis was used to formulate strategy. The results showed that although Kepung District has LSO as organic certified region on rice, but some farmers still conducting conventional farming. Farmers are also find difficulty in market their product. Development strategies can be focused on strengthening farmer group institutions especially in seraching for wider target market.
\end{abstract}

\section{KEY WORDS}

Rice, organic farming, food safety.

Organic farming is an agricultural technology package that not only concerns to the availability of food in the form of productivity but also environmentally friendly. It is a technique that relies on natural ingredients without the use of synthetic chemicals. Anorganic fertilizers or chemical fertilizers are considered as the cause of pollution of ground water such as rivers and lakes. It is, in addition, also lower soil quality especially if the use of it is not appropriate (Syam, 2008).

The main objective of organic farming is to provide agricultural products, especially food that is safe for the health of producers and consumers and environmental friendly. Healthy lifestyle has been institutionalized internationally that requires assurance that agricultural products must be safely consumed, have high nutrients and be environmentally friendly. Consumer preferences like this and economic development cause the demand for organic agricultural products of the world that increased rapidly (Mayrowani, 2012).

The development of organic agriculture in Indonesia has been encouraged by the current government through Regulation of the Minister of Agriculture No. 64 of 2013 on organic farming system. To cope well with the opportunities, the challenges faced in the development of rice in the future are how domestic rice production can compete in the export market. To meet the market demand is through the development of organic rice. In Indonesia the development of organic rice is a small part of the agribusiness, but certainly the trend is always increasing from year to year. The development of organic farming area in Indonesia can be seen in table 1.

Based on table 1, it is known that from 2012 to 2015 the area of land for organic 
farming has fluctuations. The wider area of organic agriculture is expected to provide broad benefits in meeting the needs of the community for healthy and safe food. Demand of organic rice in Indonesia is fluctuate from 28,95 tonnes to 73,55 tonnes (2011-2014) and then grows-up in 2015 to 2016 (see Table 2), it needs to be paid attention as the opportunity to export agriculture product abroad. While in the domestic, the opportunities of increasing consumer demand for organic food cannot be utilized optimally because the production tends to remain and the area of organic certified land has not been maximal. Table 3 shows consumer demand in a case study of organic red rice production in Subak Wongayabetan Bali.

Table 1 - Organic Agriculture Areal Year in Indonesia (2012 - 2015)

\begin{tabular}{|c|c|c|c|c|}
\hline Orgnik Land Type & 2012 & 2013 & 2014 & 2015 \\
\hline Sertification & $62.127,82$ & $76.013,20$ & $67.426,57$ & $79.833,83$ \\
\hline Convertion & 744,62 & 908,96 & $1.269,31$ & 236,35 \\
\hline Without sertification & $1.382,88$ & 31,38 & $1.142,44$ & $31.381,44$ \\
\hline PAMOR & 50,79 & 36 & 36 & 36 \\
\hline Currently in the certification process & $149.462,06$ & 144.220 .05 & $146.571,40$ & $149.896,03$ \\
\hline TOTAL & $213.768,17$ & $221.209,59$ & $216.445,72$ & $261.383,65$ \\
\hline
\end{tabular}

Source: Compilation of SPOI 2012-2016.

Table 2 - Data on demand for (exports) of organic rice in 2009 - 2014 (in Tons)

\begin{tabular}{|c|c|}
\hline Year & Demand \\
\hline 2010 & 30,00 \\
\hline 2011 & 28,95 \\
\hline $2012^{*}$ & 66,63 \\
\hline $2013^{*}$ & 62,15 \\
\hline $2014^{*}$ & 73,55 \\
\hline 2015 & 277,9 (exports) \\
\hline 2016 & 300 (exports) \\
\hline
\end{tabular}

Source: Compilation from Indonesian Organic Agriculture Statistics, 2011, ${ }^{\star}$ prediction and Ministry of Republic of Indonesia, 2017.

Table 3 - Production and Demand for Organic Red Rice in Subak Wongayabetan

\begin{tabular}{|c|c|c|}
\hline Year & Production (tons) & Demand (tons) \\
\hline 2010 & 43,79 & 57 \\
\hline $2011^{*}$ & 43,84 & 68 \\
\hline $2012^{*}$ & 43,89 & 75 \\
\hline $2013^{*}$ & 43,95 & 82 \\
\hline
\end{tabular}

Source: Statistik Pertanian Organik Indonesia, 2011, *prediction.

The position of rice as the staple food of the people of Indonesia makes rice commodity as the main commodity in organic agriculture which is developed. In the Statistics of Organic Agriculture Indonesia (SPOI) noted that in 2010 the area of organic rice reaches 3000 ha that have been certified. Organic rice is processed into organic rice is a food that is easily converted into energy, in addition to contains enough nutrients and boosters for the body (Mayrowani,2012).

Kediri Regency is one of the potential areas for the development of organic rice that can contribute in realizing organic food. Some locations of organic farming in Kediri Regency are located in Kepung and Semen Subdistricts. Geographically the location of the sub-district is located in the upstream area with the condition of natural resources and ecosystem that is still pure, so that the area is potential for the development of organic farming. The average production of organic rice farming in Kediri regency is $8,098,36 \mathrm{~kg}$ per hectare per year and this can be categorized as sufficient production (Kurniawan, 2016). Based on the background, this research has aim to understand (1) the characteristics of organic rice farmers, (2) organic farming implementation and (3) to give recommendation strategy to developing organic rice farming in Kepung Subdistrict Kediri. 


\section{LITERATURE REVIEW}

Rice is a plant that belongs to the genus Oryza L. which includes approximately 25 species spread in the tropics and subtropical regions. Rice is one of the food crop varieties that can be cultivated organically. The Ministry of Agriculture has set standards for organic agriculture in Indonesia, contained in SNI 01-6729-2002 and has been revised to become SNI for Organic Food System SNI 6729-2010. Whereas the Provisions regarding the rules of organic farming applied in Indonesia are in accordance with the Indonesian National Standards for Organic Food Systems namely SNI Number 6729 of 2002 which was followed by Permentan Number 64 of 2013 (Directorate General of Food Crops, Ministry of Agriculture of the Republic of Indonesia, 2015).

The organic farming system adheres to the Organic Process concept, meaning that all organic farming system processes starting from land preparation to post-harvest meet the standards of organic cultivation, not seen from the organic products produced. Organic rice cultivation will produce rice that is free of pesticide residues and chemical fertilizers. Apart from being environmentally friendly, the cost of planting is very low because the fertilizers and pesticides used come from nature around the farmers (Agricultural Human Resources Development and Development Agency of the Republic of Indonesia, 2011).

The way to grow organic rice is basically not different from conventional rice cultivation (non-organic). The only difference is in the selection of varieties and the use of basic fertilizers. Not all suitable rice varieties are cultivated organically. Rice varieties that are suitable to be planted in 9 organic species are only natural varieties. The 2 types of organic rice varieties are Cintanur and Ciherang. Organic fertilizers that are often used to fertilize plants are compost. Compost is an organic fertilizer that comes from the rest of plants, animals, and organic waste that has undergone a process of decomposition. The total conversion of fertilizers does not use inorganic fertilizers such as urea, TSP or $\mathrm{KCl}$ at all. Organic rice requires 4 tons of manure and legume compost / ha. Control of pests and diseases of organic rice plants can be done by: (1) Mechanical control is carried out by directly capturing pests or using traps; (2) Control by technical culture is carried out by planting host plants around organic rice fields; (3) Control using organic pesticides which can control pest stink pest, stem borer, brown planthopper, and green planthopper. Organic rice has good market prospects, because organic rice farming has the opportunity to continue to be improved and allows to produce higher profits compared to non-organic rice farming. Organic rice cultivation can be done by utilizing the surrounding environment so that input costs become cheaper. Besides that, the price of organic rice is higher than the price of nonorganic rice (Directorate General of Food Crops, Ministry of Agriculture of the Republic of Indonesia, 2015).

To find out the financial benefits of a farm, it can be known by using incremental B / C Ratio, which is the difference in revenues with costs (Suratiyah, 2006 in Nugroho, 2013):

$$
\mathrm{B} / \mathrm{C} \text { Ratio }=\Delta \mathrm{B} / \Delta \mathrm{C}
$$

Where: $\mathrm{B}=$ Benefit; $\mathrm{C}=$ Cost.

Financial Analysis of Ciherang Rice Farming in the Jajar Legowo Planting System in Sungai Tabukan Subdistrict North Hulu Sungai Regency, South Kalimantan aims to determine the feasibility of Ciherang rice farming (Saihani, 2012). The research uses formulas:

$$
\mathrm{RCR}=\mathrm{TR} / \mathrm{TC}
$$

Where: $\mathrm{RCR}=$ Revenue Cost Ratio; $\mathrm{TR}=$ Total Penerimaan; $\mathrm{TC}=$ Total Biaya .

The qualitative approach in the SWOT matrix displays eight boxes, namely the top two are boxes of external factors (opportunities and challenges), while the two boxes on the left are internal factors (strength and weakness) (Rangkuti, 2006).

Formulation of the Strategy for the Development of the Benefit Sharing Model in the MSME financing scheme of the Organic Rice Institution Agribusiness sector in Kediri 
Regency is done by means of integrating the internal and external factors contained in the SWOT matrix. The other four boxes are boxes of strategic issues that arise as a result of meeting points between the internal and external factors of institutional organic rice.

Menurut Rangkuti (2006), SWOT is used in identifying various factors systematically for later use in strategy formulation. The combination of internal and external factors will greatly affect the performance of the company. SWOT is applied by comparing external factors in the form of opportunities and threats with internal factors in the form of strengths and weaknesses of the company or organization. Determination of alternative development strategies should be formulated after the institution or organization analyzes the quadrant which conditions and position of the current institution or organization. This is intended, so that alternative alternatives are in accordance with the internal and external conditions of the institution in this case micro, small and medium enterprises at this time.

\begin{tabular}{|c|c|c|}
\hline Eksternal Internal & $\begin{array}{l}\text { Strengths (S) } \\
1 . \\
2 . \\
3 .\end{array}$ & $\begin{array}{l}\text { Weaknesses (W) } \\
1 . \\
2 . \\
3 .\end{array}$ \\
\hline $\begin{array}{l}\text { Threat }(\mathrm{T}) \\
1 . \\
2 . \\
3 .\end{array}$ & $\begin{array}{l}\text { Strategi ST } \\
\text { Cunakan S untuk } \\
\text { menghindari T }\end{array}$ & $\begin{array}{l}\text { Strategi WT } \\
\text { Minimalkan W dan } \\
\text { hindari T }\end{array}$ \\
\hline $\begin{array}{l}\text { Opportunity (0) } \\
1 . \\
2 . \\
3 .\end{array}$ & $\begin{array}{l}\text { Strategi SO } \\
\text { Gunakan S untuk } \\
\text { memanfaatkan O }\end{array}$ & $\begin{array}{l}\text { Strategi WO } \\
\text { Atasi W dengan } \\
\text { memanfaatkan } 0\end{array}$ \\
\hline
\end{tabular}

Figure 1 - Internal and External Factors (Rangkuti, 2006)

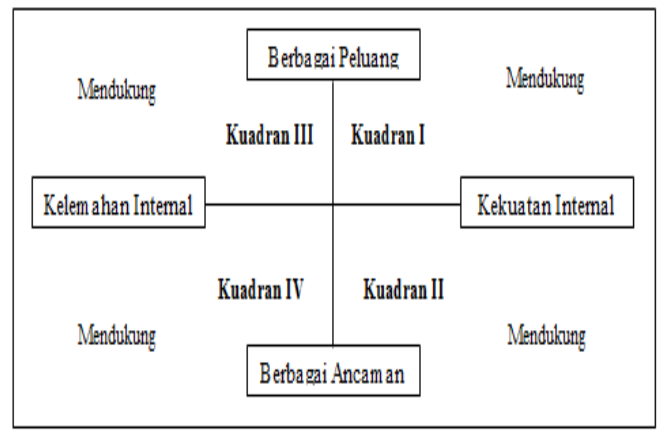

Figure 2 - Company Position in Four Quadrants (Rangkuti, 2006)

In quadrant I, a company is advised to use an aggressive strategy. The situation of quadrant I company is very profitable, because the location of the company that is in a condition has the opportunity and strength so it is necessary to be able to take advantage of the opportunities that exist.

In quadrant II, the company's strategy is a diversification strategy. Companies facing a situation must face various threats by using internal strength, so that they need a strategy that is able to take advantage of long-term opportunities.

In quadrant III, the appropriate strategy to implement is turn around. In this condition the company has a large market opportunity but is accompanied by the emergence of considerable internal constraints / weaknesses. Companies need to formulate strategies that allow reduction of their internal weaknesses to be able to take advantage of better opportunities.

In quadrant IV, a defensive strategy is needed. The company experiences difficult conditions where it must face various threats and internal weaknesses of the company. The most important thing to do is that companies must be able to defend themselves. 


\section{METHODS OF RESEARCH}

This is a descriptive-qualitative research located in Kepung Sub district Kediri. It uses primary data related to production factors, costs and revenue was collected through interview with 30 farmers in May-June 2017. Data were analyzed descriptively by using information on farming system conducted by farmer, then, SWOT analysis was used to formulate strategy. SWOT is strategic planning tool consists of elements such as strength, weakness, opportunity, and threat. It is done by determining each elements including the weight and rating. The next step is counting the total score of every elements to determine the best strategy (Rangkuti, 2006).

\section{RESULTS AND DISCUSSION}

Characteristics of organic rice farmers. Farmers of indonesia has different characteristic. These characteristics can be demographic, social character and character based on farmer's economic condition itself. These characteristics distinguish the type of peasant behavior in certain situations. Characteristics observed in this study were age, education level, sex, and land area.

Organic rice farmers are mostly men who are their in middle age $(43 \%)$ and young $(40 \%)$. While only $17 \%$ of them are old in term of age. A person's age determines the person's work performance. The older the workforce the absorptive power and the comprehension of innovation - more difficult new application of agriculture to accept. But in terms of responsibilities the older the workforce will not give significant influence because they are more experienced.

Education will affect behavior and adoption rate of an innovation. Someone who is well educated tends to be more open to accept and try new things. Education is a learning tool, which instills a sense of attitude and also beneficial to the development of more modern agricultural practices. In this research, farmers are mostly has mid level of education $(77 \%)$. However, they have the knowledge of farming mostly from informal education more than formal education such as from agricultural extension.

Table 4 - Description of Organic Farmers in Kepung Sub District Kediri

\begin{tabular}{|c|c|c|c|c|c|}
\hline \multirow{2}{*}{ No. } & \multirow{2}{*}{ Characteristic of Farmers } & \multicolumn{4}{|c|}{ Amount } \\
\hline & & \multicolumn{2}{|c|}{ Category } & $\mathrm{N}$ & $\%$ \\
\hline \multirow{3}{*}{1.} & \multirow{3}{*}{ Age (based on KRKP, 2015) } & not yet productive & $0-14$ & 0 & 0 \\
\hline & & productive & $15-64$ & 27 & 90 \\
\hline & & not productive & $>64$ & 3 & 10 \\
\hline \multirow{3}{*}{2.} & \multirow{3}{*}{ Education level } & low level & $<$ SMP & 5 & 17 \\
\hline & & mid level & SMP-SMU & 23 & 77 \\
\hline & & high level & Graduate & 2 & 7 \\
\hline \multirow{3}{*}{3.} & \multirow{3}{*}{ Land area width } & low & $0-0,50 \mathrm{H}$ & 24 & 80 \\
\hline & & middle & $0,51-1,00 \mathrm{H}$ & 2 & 6,67 \\
\hline & & High & $>1 \mathrm{H}$ & 4 & 13,37 \\
\hline \multirow{3}{*}{4.} & \multirow{3}{*}{ Land planted with organic rice } & rendah & $0,006-0,67 \mathrm{H}$ & 29 & 97 \\
\hline & & sedang & $0,67-1,34 \mathrm{H}$ & 0 & 0 \\
\hline & & tinggi & $1,35-2 \mathrm{H}$ & 1 & 3 \\
\hline
\end{tabular}

Source: Primary data, 2017.

Table 4 also shows that most farmers are the land owner, however they have small scale of area $(80 \%)$ that is only $0,006-0,67$ hectares while the rest of them has middle even high land area width. Farmers of organic rice use not all part of their land to conduct organic rice farming. Most of them (97\%) use only small part of their land, while the rest of it $(3 \%)$ uses all part of their land. From this fact it can be seen that organic farming is not yet becoming their priority, however this will give opportunity for agricultural extension worker to motivate them to conduct organic farming for better ecosystem.

Organic farming implementation in Kepung Kediri. The soil is plowed as deep as 25 - 
$30 \mathrm{~cm}$, then the remains of plants and grasses are buried. Grounding with rake is done until a perfect mud structure is formed, then the mud is flattened so that when it is irrigated, the height is evenly distributed. Fertilization with organic fertilizer (manure, compost and green manure) is done to prepare a good land for plants.

To get a good quality seeds then the selection of seeds. Figure 4 shows the type of seed used in organic rice farming. The seeds are produced by farmers or labeled seeds.

The seedbed is done by preparing the nursery where it is coated with banana leaf that has been softened, then it is given fertile soil mixed with compost (ratio 1: 1), the height of nursery around $4 \mathrm{~cm}$. Then, the Seed is sown into the seedbed and covered with thin ground.

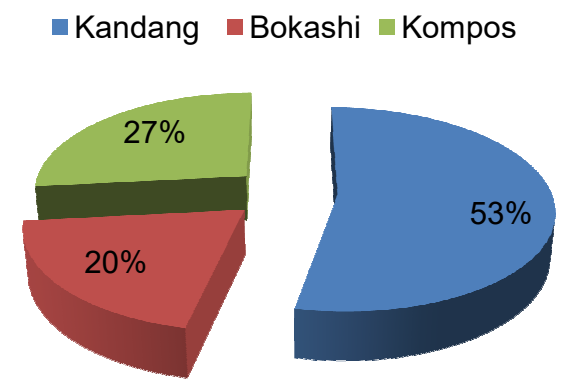

Figure 2 - Organic Fertilizer

\begin{tabular}{|c|c|}
\hline - Daun Alpukat $\square$ Murih & - Tembakau \\
\hline - Daun Gadung ${ }^{-}$Asap Cair & - Serai \\
\hline
\end{tabular}

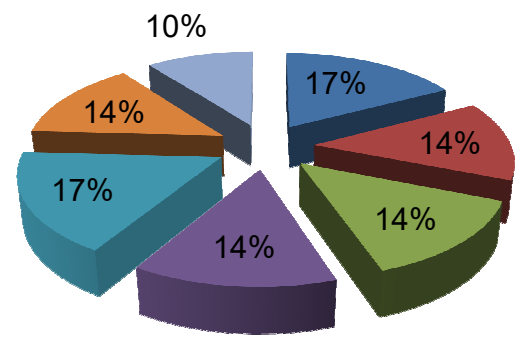

Figure 3 - Herbal Pesticide

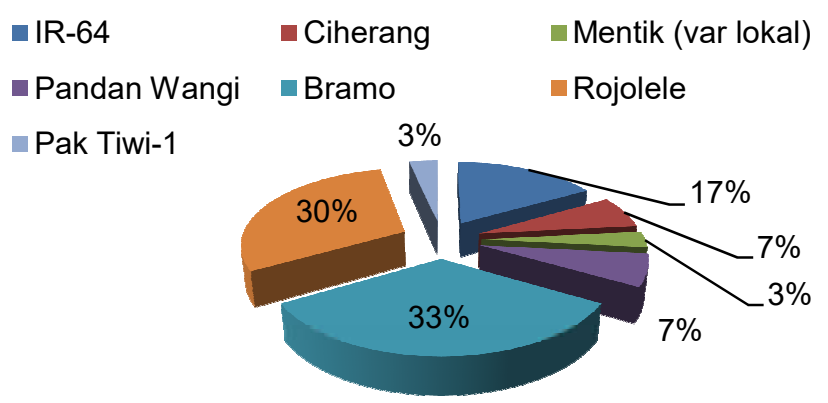

Figure 4 - Variety of Organic Paddy seedling

Seedlings are planted at the age of 5-15 days (leaf two) after the seedlings, with the number of seeds per hole one, and shallow $1-1.5 \mathrm{~cm}$, and the root position like the letter $\mathrm{L}$.

Fertilization has not been done purely using organic fertilizer, partly using an organic fertilizer. But the amount of organic fertilizer used is relatively more benyak than an organic. 
Weeding is done by using a rotary weeder, or with any kind of equipment in order to eradicate weeds and simultaneously enrich the soil. Weeding done as much as 3 times or more.

Harvesting is done after the mature organic rice is characterized by yellowing all the grain evenly or cooking grain. Harvesting is done when the organic rice grain has completely filled. When calculated from the nursery, the age of organic rice harvest is shorter than the conventional way. Table 5 shows average production, cost, revenue and income. It also shows that organic rice cultivation in Kepung sub district is feasible in price of Rp 15.000 20.000 because in this way, farmers will get income as much as Rp 25.585.613.

Table 5 - Average Production, cost, revenue, income and R/C Ratio of Organic Rice Farming

\begin{tabular}{ccc}
\hline No. & Note & Amount \\
\hline 1. & Average of production $(\mathrm{kg} / \mathrm{ha})$ & 2.232 \\
2. & Price of dry grain $(\mathrm{Rp})$ & Rp. $15.000-20.000$ \\
3. & Average of production cost $(\mathrm{Rp} / \mathrm{ha})$ & Rp. 13.849 .387 \\
4. & Average of revenue $(\mathrm{Rp} / \mathrm{ha})$ & Rp. 39.435 .000 \\
5. & Average of income $(\mathrm{Rp} / \mathrm{ha})$ & 25.585 .613 \\
6. & Average of R/C & 2,85 \\
\hline
\end{tabular}

Source: Primary data, 2017.

In general, the emphasis on institutional activities of farmer groups is not to provide capital services for its members, but to the management of collective resources (eg irrigation arrangements and planting schedules) and social life as practiced by KUD Kelompok Tani Budidaya. This KUD is able to produce organic fertilizer sold in general with the price of (Bokasi Trikodermin fertilizer) Rp.30.000 / sack, Organic liquid fertilizer from goat urine is Rp.40.000, Liquid smoke (for pest spray) is only for Rp.40.000 / liter and Local mikro organic (MOL) is Rp.30.000.

As a post-harvest institution, KUD of Budi Daya farmer group has served as a regulator of the selling price of organic rice, in order not to experience a sharp price declining during the harvest. While related to marketing, KUD of Budi Daya Farmer Group has had simple equipment in the process of packing organic rice. For pure organic rice products, farmer groups sell for around Rp.17.000-20.000 / kg under the Parikesit trademark.

Table 6 - Internal Factors Analysis Summary of SWOT

\begin{tabular}{|c|c|c|c|c|}
\hline No. & Strength $(0.40)$ & Rate (R) & Weight (W) & $\mathrm{R} \times \mathrm{W}$ \\
\hline 1. & Organic rice has local label called "Parikesit" & 3 & 0,05 & 0,15 \\
\hline 2. & The number of farmers as organic paddy grower can increase & 3 & 0,05 & 0,15 \\
\hline 3. & There is good institution to support the farm management of organic paddy & 4 & 0,1 & 0,4 \\
\hline 4. & $\begin{array}{l}\text { There is government support in term of agricultural extension that is regularly done to } \\
\text { motivate farmers in planting organic paddy }\end{array}$ & 4 & 0,1 & 0,4 \\
\hline \multirow[t]{2}{*}{5.} & Integrated farming has been done by farmers to support organic paddy cultivation & 3 & 0,1 & 0,3 \\
\hline & $\begin{array}{l}\text { Weaknesses } \\
(0.60)\end{array}$ & $\begin{array}{l}\text { Rate } \\
(\mathrm{R})\end{array}$ & $\begin{array}{l}\text { Weight } \\
\text { (W) }\end{array}$ & $\mathrm{R} \times \mathrm{W}$ \\
\hline 1. & There is not yet patent label and it is still produce locally. & -2 & 0,1 & $-0,2$ \\
\hline 2. & $\begin{array}{l}\text { The continuity of organic rice availability is still low, due to the lack of interest and } \\
\text { motivation of farmers }\end{array}$ & -2 & 0,1 & $-0,2$ \\
\hline 3. & $\begin{array}{l}\text { Farmers have difficulties in marketing organic rice widely because of constrained } \\
\text { knowledge and lack of licensing as well as lack of access of capital }\end{array}$ & -4 & 0,2 & $-0,8$ \\
\hline 4. & $\begin{array}{l}\text { The practice of organic farming implementation has not been done purely, there are } \\
\text { still the use of chemicals substances such as the using of fertilizers and chemical } \\
\text { pesticides }\end{array}$ & -3 & 0,1 & $-0,3$ \\
\hline 5. & Farmers produce organic rice only by orders & -3 & 0,1 & $-0,3$ \\
\hline
\end{tabular}

Source: Primary data, 2017.

Government as a policy maker has a strategic role in the development of organic rice in Kediri region, especially related to the dissemination of innovation through extension activities. Agricultural extension has been done by Mr. Sunandar who has short-term program to apply organic cultivation technology, because not all farmers understand the cultivation. As many as $70 \%$ of farmers have implemented organic cultivation well and this 
will be continued in the long term, that is farming by restoring the ecosystem balance system. Extension workers also develop strategies related to how to communicate innovations to be easily digested by farmers through the best extension methods.

Strategy to develop organic rice farming in Kepung Subdistrict Kediri. People's desire to switch to organic produce causes the demand for organic agricultural products to grow rapidly. Organic farming is a solution to restore the health of the land and the resulting product. Based on the previous discussion it can be seen that organic rice cultivation is feasible, but farmers tend to be afraid to take risks and this can be seen from the narrowness of land used for organic farming of the entire land area owned by farmers. SWOT analysis in table 6 and 7 shows internal and external factors need to be paid attention to develop organic rice farming in Kediri.

From internal and external factors shown in table 6 and 7, it can be seen that agribusiness of organic rice in Kediri is categorized in condition that is weak and full of threat $(-0,4,-1)$. The best strategy is Defense Strategy. This strategy is based on defensive activities and seeks to minimize weaknesses and avoid threats. The WT strategy aims to reduce internal weaknesses by avoiding external threats.

Table 7 - External Factors Analysis Summary of SWOT

\begin{tabular}{|c|c|c|c|c|}
\hline No. & Opportunity $(0.60)$ & Rate (R) & Weight (W) & $\mathrm{R} \times \mathrm{W}$ \\
\hline 1. & $\begin{array}{l}\text { The market share of organic rice is still widely open due to healthy lifestyles that } \\
\text { are increasingly being noticed by the community }\end{array}$ & 3 & 0,1 & 0,3 \\
\hline 2. & The area for organic farming can be improved & 4 & 0,1 & 0,4 \\
\hline 3. & $\begin{array}{l}\text { Agricultural extension bureau in Kediri has a good system in introducing organic } \\
\text { farming to motivate farmers to grow organic rice }\end{array}$ & 4 & 0,2 & 0,8 \\
\hline 4. & $\begin{array}{l}\text { There is a widely open partnership or synergy of stakeholders that facilitate the } \\
\text { marketing of organic rice }\end{array}$ & 4 & 0,2 & 0,8 \\
\hline No. & $\begin{array}{l}\text { Threats } \\
(0.40)\end{array}$ & Rate (R) & Weight (W) & $\mathrm{R} \times \mathrm{W}$ \\
\hline 1. & $\begin{array}{l}\text { There is high competition of market with non-organic rice, because organic rice is } \\
\text { still very expensive }\end{array}$ & -4 & 0,1 & $-0,4$ \\
\hline 2. & Land degradation due to the use of chemical or fertilizers & -3 & 0,1 & -0.3 \\
\hline 3. & $\begin{array}{l}\text { Organic farming has a long process to do while farmers need income to meet } \\
\text { family needs }\end{array}$ & -3 & 0,1 & $-0,3$ \\
\hline 4. & Conversion of agricultural land for the benefit of settlement & -3 & 0,1 & $-0,3$ \\
\hline
\end{tabular}

Source: Primary data, 2017.

Table 8 - Strategy to develop organic rice farming in Kepung Subdistrict Kediri through SWOT Analysis

\begin{tabular}{|c|c|c|}
\hline $\mathrm{n} / \mathrm{n}$ & $\begin{array}{l}\text { Opportunity } \\
\text { The market share of organic rice is still } \\
\text { widely open due to healthy lifestyles that are } \\
\text { increasingly being noticed by the } \\
\text { community; } \\
\text { The area for organic farming can be } \\
\text { improved; } \\
\text { Agricultural extension bureau in Kediri has a } \\
\text { good system in introducing organic farming } \\
\text { to motivate farmers to grow organic rice; } \\
\text { There is a widely open partnership or } \\
\text { synergy of stakeholders that facilitate the } \\
\text { marketing of organic rice }\end{array}$ & $\begin{array}{l}\text { Threat } \\
\text { There is high competition of market } \\
\text { with non-organic rice, because } \\
\text { organic rice is still very expensive; } \\
\text { Land degradation due to the use of } \\
\text { chemical or fertilizers; } \\
\text { Organic farming has a long process } \\
\text { to do while farmers need income to } \\
\text { meet family needs; } \\
\text { Conversion of agricultural land for } \\
\text { the benefit of settlement. }\end{array}$ \\
\hline $\begin{array}{l}\text { Strengths } \\
\text { Organic rice has local label called } \\
\text { "Parikesit"; } \\
\text { The number of farmers as organic } \\
\text { paddy grower can increase; } \\
\text { There is good institution to support the } \\
\text { farm management of organic paddy; } \\
\text { There is government support in term of } \\
\text { agricultural extension that is regularly } \\
\text { done to motivate farmers in planting } \\
\text { organic paddy; } \\
\text { Integrated farming has been done by } \\
\text { farmers to support organic paddy } \\
\text { cultivation. }\end{array}$ & $\begin{array}{l}\text { SO Strategy } \\
\text { marketing subsystem in KUD Budi Daya can } \\
\text { be improved by cooperating with suppliers } \\
\text { such as supermarket; } \\
\text { taking licensing and getting certified so as to } \\
\text { reach broad consumers; } \\
\text { increase the implementation of integrated } \\
\text { farming to support organic farming, and } \\
\text { maximize institutional function as a place for } \\
\text { marketing by establishing cooperation with } \\
\text { the government for example in terms of } \\
\text { providing equipment for post-harvest } \\
\text { process and packaging. }\end{array}$ & $\begin{array}{l}\text { ST Strategy } \\
\text { Regular agricultural extension is } \\
\text { important to motivate farmers in } \\
\text { conducting organic cultivation and } \\
\text { also in terms of expanding organic } \\
\text { land to increase crop productivity; } \\
\text { increase the role of KUD to } \\
\text { accommodate organic rice harvest } \\
\text { and also marketing; } \\
\text { KUD can also work with the } \\
\text { government to get the aid of } \\
\text { packaging equipment, trade } \\
\text { licensing, and also marketing to } \\
\text { reach consumers widely. }\end{array}$ \\
\hline
\end{tabular}




\begin{tabular}{|c|c|c|}
\hline \multicolumn{3}{|l|}{ Table 8 Continue } \\
\hline $\begin{array}{l}\text { Weaknesses } \\
\text { There is not yet patent label and it is still } \\
\text { produce locally; } \\
\text { The continuity of organic rice availability } \\
\text { is still low, due to the lack of interest and } \\
\text { motivation of farmers; } \\
\text { Farmers have difficulties in marketing } \\
\text { organic rice widely because of } \\
\text { constrained knowledge and lack of } \\
\text { licensing as well as the difficulty in } \\
\text { accessing the capital; } \\
\text { The practice of organic farming } \\
\text { implementation has not been done } \\
\text { purely, there are still the use of } \\
\text { chemicals substances such as the using } \\
\text { of fertilizers and chemical pesticides; } \\
\text { Farmers produce organic rice only by } \\
\text { orders. }\end{array}$ & $\begin{array}{l}\text { WO Strategy } \\
\text { certification tests need to be done to patent } \\
\text { labels and obtain organic nutritional content } \\
\text { so it is worth selling; } \\
\text { Agricultural extension needs to be done to } \\
\text { improve farmers' knowledge about good } \\
\text { agricultural cultivation; } \\
\text { cooperation with stakeholders for example } \\
\text { to overcome the weakness of marketing } \\
\text { also by increasing the role of agricultural } \\
\text { academics. }\end{array}$ & $\begin{array}{l}\text { WT Strategy } \\
\text { Nutrition testing needs to be done to } \\
\text { raise awareness that organic } \\
\text { products have health-intensive } \\
\text { content; } \\
\text { counseling needs to be done by } \\
\text { involving comparative studies to } \\
\text { places that have been carrying out } \\
\text { organic cultivation and proven to be } \\
\text { profitable thus increasing the } \\
\text { farmers expectations; } \\
\text { overcome land degradation by } \\
\text { expanding the land for organic } \\
\text { farming; } \\
\text { expand the reach of marketing to } \\
\text { demand not only through orders } \\
\text { alone, such as cooperation with } \\
\text { supermarkets and online marketing. }\end{array}$ \\
\hline
\end{tabular}

Source: Primary data, 2017.

Table 8 shows the best strategy (Defense strategy) and it consists:

- Nutrition testing needs to be done to raise awareness that organic products have health-intensive content;

- Counseling needs to be done by involving comparative studies to places that have been carrying out organic cultivation and proven to be profitable thus increasing the farmers expectations;

- Overcome land degradation by expanding the land for organic farming;

- Expand the reach of marketing to demand not only through orders alone, such as cooperation with supermarkets and online marketing.

\section{CONCLUSION}

Most farmers are in middle and old age, with $100 \%$ of land owner, this is generation with low knowledge. However they have more than 5 years of experinence in farm management that helps them master the knowledge of organic plantation easily.

Farmers of Kepung Kediri still not yet implemented $100 \%$ pure organic activity, this is shown by the using of production factors especially for manure and pesticides. Agriculture institution has big role in helping to provide input and marketing the product by orders.

Turn Around strategy is the best strategy in handling organic farm management of rice. Synergy between stake holders is needed in empowering organic farmers through the Community Empowerment Strategy such as partnership in marketing. Development strategies can be focused on strengthening farmer group institutions especially in seraching for wider target market.

\section{ACKNOLEGEMENTS}

We would like to thank Indonesian Ministry of Research, Technology and Higher Education and University of Brawijaya especially the Research and Community Services Institution.

\section{REFERENCES}

1. Aliansi Organis Indonesia, 2011. Statistika Pertanian Organik Tahun 2011. Jakarta: AOI Press.

2. Aliansi Organis Indonesia, 2017. Statistik Pertanian Organik Indonesia 2016. Edisi Pertama. Bogor: AOI Press.

3. Syam, M. 2008. Padi Organik dan Tuntutan Peningkatan Produksi Beras. Jurnal Iptek Tanaman Pangan Vol. 3 No. 1 - 2008 halaman 2. 
4. Mayrowani, H. 2012. Pengembangan Pertanian Organik di Indonesia. Forum Penelitian Agro Ekonomi, Volume 30 No. 2, Desember 2012: 91 - 108 halaman 93.

5. Koalisi Rakyat Kedaulatan Pangan (KRKP), 2015. Laporan Kajian Regenerasi Petani: Pada Petani Padi dan Tanaman Hortikultura. Bogor: KRKP dan IPB.

6. Kurniawan, 2016. The Development Prospect of Agribusiness Rice Organic in Kediri for Supporting the Resilience Food Program in East Java. Jurnal Ilmiah Inovasi, Vol. 1. No. 1. Hal. 23-32, Edisi Januari-April.

7. Rangkuti, F. 2006. Teknik Membedah Kasus: Analisis SWOT. Jakarta: PT. Gramedia Tbk. 